\title{
De-Westernizing Creative Labour Studies The Informality of Creative Work from an Ex-Centric Perspective
}

\author{
Alacovska, Ana; Gill, Rosalind
}

Document Version

Accepted author manuscript

Published in:

International Journal of Cultural Studies

DOI:

$10.1177 / 1367877918821231$

Publication date:

2019

License

Unspecified

Citation for published version (APA):

Alacovska, A., \& Gill, R. (2019). De-Westernizing Creative Labour Studies: The Informality of Creative Work from an Ex-Centric Perspective. International Journal of Cultural Studies, 22(2), 195-212. https://doi.org/10.1177/1367877918821231

Link to publication in CBS Research Portal

\section{General rights}

Copyright and moral rights for the publications made accessible in the public portal are retained by the authors and/or other copyright owners and it is a condition of accessing publications that users recognise and abide by the legal requirements associated with these rights.

Take down policy

If you believe that this document breaches copyright please contact us (research.lib@cbs.dk) providing details, and we will remove access to the work immediately and investigate your claim. 


\section{De-Westernizing Creative Labour Studies: The Informality of Creative Work from an Ex-Centric Perspective}

\section{Ana Alacouska and Rosalind Gill}

Journal article (Accepted manuscript*)

\section{Please cite this article as:}

Alacovska, A., \& Gill, R. (2019). De-Westernizing Creative Labour Studies: The Informality of Creative Work from an Ex-Centric Perspective. International Journal of Cultural Studies, 22(2), 195-212. https://doi.org/10.1177/1367877918821231

DOl: https://doi.org/10.1177/1367877918821231

Copyright (ㅇ The Author(s) 2019. Reprinted by permission of SAGE Publications.

* This version of the article has been accepted for publication and undergone full peer review but has not been through the copyediting, typesetting, pagination and proofreading process, which may lead to differences between this version and the publisher's final version AKA Version of Record.

Uploaded to CBS Research Portal: May २०२० 


\title{
De-Westernising creative labour studies: The informality of creative work from an ex-centric perspective
}

Ana Alacovska, Associate Professor, Copenhagen Business School, Denmark Email: aa.msc@cbs.dk

Rosalind Gill, Professor, City, University of London, UK Email: rosalind.gill.2@city.ac.uk

Funding statement: This research was supported by funding from the Swiss Agency for Development and Cooperation (grant number: MKD_211, RRPP).

\begin{abstract}
Creative labour studies focus almost exclusively on Euro-American metropolitan 'creative hubs' and hence the creative worker they theorize is typically white, middle-class, urban and overwhelmingly male. This article outlines the contours of a de-Westernising project in creative labour studies while introducing a special journal issue that examines the lived dynamics of creative work outside the West. The article advocates an 'ex-centric perspective' on creative work. An ex-centric perspective does not merely aim at multiplying non-West empirical case studies. Rather, it aims at destabilizing, decentring and provincializing the taken-for-grantedness of some entrenched notions in creative labour studies such as informality and precarity. An ex-centric perspective, we contend, offers a potential challenge to many of the claims about creative work that have taken on the status of general truths and universal principles in spite of them being generated from limited empirical evidence gleaned from research sites situated almost exclusively in the creative hubs of Euro-America.
\end{abstract}

Keywords: de-Westernizing, de-Westernisation, creative labour, cultural work, media work, creative industries, informality, precarity, precariousness, creative cities

\section{Introduction}

Media and cultural studies are increasingly stirred by calls for 'de-Westernisation', alongside longstanding critiques of imperialism and colonialism (Césaire, 2001), and growing voices concerned to decolonize the academy, its research and curricula (Santos, 2014; Nabudere, 2011; Giraldo, 2016). Some scholars have acutely observed that media and cultural theory has a persistent tendency to become 'self-absorbed' and 'parochial', deriving universalistic claims from 'a tiny handful of countries' usually situated at the centre of 'the Anglo-American orbit' (Curran and Park, 2000: 2 and 11; Sreberny, 2000; Thussu, 2000; Hanitzsch, 2007; Wang, 2010). All such 'de-westernising' voices share a common concern that universalistic claims inferred from geographically circumscribed empirical evidence promote Western ideals as general (hegemonic) sources and mechanisms of knowledge. In response, scholarly 
calls for 'internationalizing' or 'globalizing' cultural studies have become ever stronger in advocating the need to conduct studies situated in the 'non-West' (Wright, 1998; Shome, 2009; Orgad, 2012) as an antidote to the parochialism of cultural studies. For many such 'internationalization' should not merely imply increasing the number of empirical case studies from 'outside of the West'. Rather it requires a more critical, inclusive and 'cosmopolitan scholarship' that will actively incorporate and develop an 'excentric' perspective, the perspective outside of the Anglo-American orbit, that will challenge mainstream theory-building (Waisbord and Mellado, 2014). In doing so ex-centric perspectives should de-centre, that is 'provincialize', the universalism of Western theory (Willems, 2014) and its 'epistemological ethnocentrism' - visible in the practice of privileging Western empirical sites as 'superior ... grounds for knowledge' (Harding, 1993: 58; Santos, 2014).

The aim of this special issue is to begin to develop an ex-centric perspective in the field of creative labour studies. Creative labour studies is an increasingly salient and rapidly burgeoning subset of cultural studies (Hesmondhalgh, 2012), understood broadly in terms of the (re)turn to 'production' amidst a growing focus in academic and policy writing on the cultural and creative industries (CCl). It is an important and largely critical endeavour - in which we situate ourselves as scholars - and it has illuminated features of the working conditions, organisational forms, inequalities, and worker subjectivities that characterise work in the CCls. In terms of its focus, however, this (relatively new) body of work - mostly from the turn of the century onwards - mirrors rather than challenges the larger parochialism of cultural and communication studies. Creative labour studies are notoriously centred on Euro-American metropolitan 'creative hubs' (Barraclough and Kozul-Wright, 2008) and hence the creative worker they theorize is frequently white, middle-class, male and urban. This special Issue makes initial, and by no means complete or exhaustive, inroads into the 'de-Westernisation' of creative labour studies. Its main aim is to start a conversation about what it might mean to displace the empirical locus from the metropolitan creative epi-centres of Euro-America to 'an ex-centric site' of experience and vision situated on 'the world's peripheries' (Bhabha, 1994: 6 cited in Comaroff and Comaroff, 2012: 115). The articles included in the Special Issue thus seek to investigate the lived dynamics of creative labour and media work outside the West. However, the aim of the Special Issue is not to merely compile diversified empirical evidence 'from elsewhere' by amplifying the number and range of case studies. Rather, an ex-centric point of view should be a view that captures the 'restless, revisionary energy' of non-Euro-American work experiences (Comaroff and Comaroff, 2012: 115) and has the potential to reinvigorate, inform and de-centre the extant debates in creative labour studies. The aim is not to reverse the binary relationships - West and East or North and South, colonizer and colonised, centre and periphery- but to displace or interrupt (Trinh Minh-Ha, 1991). Like the postcolonial critic, the excentric scholar might be thought of as a 'party pooper' (Ang, 2001) who will upset and destabilise the taken for grantedness of congealed knowledge claims. The studies subscribing to this perspective refuse to apply 'universal' theoretical conclusions drawn from studies in the global North to explain the local dynamics of 'ex-centric' creative work.

An ex-centric perspective offers a potential challenge to many of the claims about creative work that have taken on the status of general truths - when they are abstracted from the specificity of particular contexts. For example, claims about precariousness or precarity have become virtually ubiquitous in 
accounts of the experiences of creative workers. Yet an ex-centric critique reveals that these understandings derive largely from research in large metropolitan centres in Western Europe, Australia and North America. In these contexts precariousness may appear as a 'deviation' or disjuncture from more stable work patterns underpinned by particular 'Western' welfare state formations, but they cannot be taken to be universal features of creative work per se, and their repeated invocation signals a parochialism vis-à-vis widespread conditions of precarity in most parts of the world. Similarly the putative 'individualization' of creative work, and the assumption that workers are passionate, aspirational, future-oriented entrepreneurial subjects should not be treated as universal or inevitable (see Alacovska, 2018a; Sandoval, 2018).

Perhaps more significant than any other claim, however, is the assertion that informality is the essential characteristic of creative work. Creative work has been typically defined as informal, involving autonomous, casual, playful and bohemian work experiences (Duffy, 2016; Neff, 2012; Ross, 2003; McRobbie, 1998). Informality has become 'the new normal' (Luckman and Taylor, 2018) of work. Even when creative labour scholars lucidly expose the soul-corrupting and exploitative effects of informal creative work-which conceals overwork, underpay and social inequalities under the guise of its very 'informality' (fun, playfulness), they may further reify the informal status as a taken-for-granted norm of creative work. The informality of creative work is so far dualistically tackled: first, as an inherent feature of creative workplaces, and second as an unregulated, network-based recruitment mechanism (for criticism see Alacovska, 2018b).

As this Special Issue will show, the lived, experienced and situated dynamics of 'informal' creative work 'outside the West' does not always reflect the same principles identified in extant studies. The contributions to this Special Issue demonstrate that informality of non-West creative work does not squarely fit into the existing binary definition of informal work. They show that the informality of creative work is multifarious, ambivalent and above all, relational-embedded in local informal economies, neighbourhoods and localized webs of collegiality, care and reciprocity.

The obdurate assumption that all creative work is 'informal' and precarious, renders 'informality' an appropriate locus for a nascent de-Westernising or 'provincializing project' (Willems, 2014). Informality of creative work has already become akin to a 'black box'-the more omnipresent a theoretical tenet the more opaque it becomes. By investigating the ways in which informality unfolds in 'ex-centric' creative work practice we hope to revise some fundamental assumptions about the intrinsically informal and precarious nature of creative work while questioning the universal validity of West-based empirical findings.

Current creative labour studies are predicated on politically important criticism of the neoliberal context in which creative labour unfolds in the West. In most cases, scholars locate their findings in the specificity of the contexts they investigate - e.g. web designers in New York (Ross, 2003), new media workers in Amsterdam (Gill, 2007), classical musicians in London and Berlin (Scharff, 2016). However, the contexts in which these studies are situated are usually large Western metropolitan creative hubs. The choice of an 'appropriate' research site for the study of creative work, is predicated on considerations of field access and sampling relating, in turn, to respondent availability, spatial proximity 
to labour market stakeholders and companies concertation (see Flew, 2013), all of which perpetuates rather than challenges, the link between 'metropolitan cities' and 'the creative class' (Florida, 2002). The problem arises when, in an academic context striated by multiple power relations - such as those relating to funding bodies, publishing house priorities, wider contexts of what counts as knowledge these studies take on the status of offering general understandings or principles regarding informality or entrepreneurial subjectivity. We cannot assume that such dynamics are universal or normative mechanisms. The 'Western' concepts of creative work have to be rethought on a broader register. We need to ask: what are the experiences elsewhere? Therefore, the provincializing approach requires cognisance of the importance of 'remote' contexts (Gibson, 2010) and the generative potential of excentric views. Such view from elsewhere can potentially help us re-imagine alternatives to the 'troubles' intrinsic to creative work, such as precarity, social inequality and psycho-somatic illness, caused by the neoliberal logic of aspiration, informality and entrepreneurial subjectivity (McRobbie, 2016; Gill, 2007).

We take inspiration from ongoing attempts to discuss 'planetary urbanisation', a process that unfolds though the universalisation of the capitalist principle of ever-accelerating growth by depleting, exploiting and usurping 'the nature' and its resources (Ruddick, 2015), a universalising practice also termed 'worlding' (Roy and Ong 2011). The worlding of the capitalist principle of growth through planetary urbanism has been identified as a challenge to environmental sustainability, biodiversity and humanity. Turning to the question of the internationalization of creative labour studies, we may think of the widespread (global) reach of neoliberal creative industries policies and the subsequent creative work studies (with their attendant 'planetary urbanism'), as worlding of informality and precarity, which has grave consequences for social equality and sustainability of creative work across geographies. The global transfer of creative industries policies (Pratt, 2010) thus mirrors the principles of planetary urbanism, mostly observable in the push for creating 'global creative cities' in the Global South. By the same token, the global spread of creative industry discourses entails also worlding of the neoliberal injunctions inherent in creative work such as informality, self-realization, autonomy, individualization, or what McRobbie (2016) calls 'the creative dispositif. In order to be able to resists the dynamics of planetary urbanism in creative work and in order to be able to imagine alternatives, one has first to call the concepts (generated in a context of neoliberal creative economy) to account and start taking local excentric specificities into consideration when theorising (and re-imagining) creative work.

\section{Ex-centric places matter: Re-contextualising and re-localising creative labour}

Recent years have witnessed a proliferation of studies of creative labour and media work. Reflecting the internal contradictions of creative labour in media industries, which are fragmented industries in themselves, these studies span a range of disciplines-sociology, geography, anthropology, media and cultural studies, as well as economy, management and organization studies. However, the emphatic interdisciplinarity of creative labour studies is not reflected in empirical heterogeneity. On the contrary, the field is riddled with epistemological ethnocentrism which casts the Western metropolis-based creative workers as the natural and logical representatives of 'global' creative work. In this sense, the creative metropolis, and its creative workers, are situated 'everywhere and nowhere' at the same time (Simone, 2010). As the viewpoint of the West becomes a universalising and essentializing 'view from 
nowhere', a localized labour dynamics is elevated to a global and universal mechanism of action (see Harding, 1993: 63).

Despite often being critical of trendy managerial discourses about 'creative cities' and 'creative nations' (Florida, 2002), studies of creative labour almost exclusively concentrate on 'funky', 'edgy' and 'cool' urban post-industrial places in the West. By implication, the creative worker and creative work so theorised is typically metropolitan and Western. London, New York, Berlin, Amsterdam are fetishized and iconic spaces of urban creativity and, by the same token, of academic investigation (Scharff, 2016; McRobbie, 2016; Neff, 2012; Banks, 2012; Gill, 2007). Outside this global super-metropolitan circuit, it is usually significant creative industries clusters and the ensuing 'flexible specialization of labour' that are an obvious research site. Studies of creative clusters thus typically focus on Los Angeles (Hollywood) as a creative hub for film labour (Scott, 2005); Nashville as 'an authentic' hometown of country music (Peterson, 1997), San Francisco (Silicon Valley) as a hotspot for new media labour (Pratt, 2002) or Milan as a main 'sartorial hub' for fashion work (McRobbie, 2016) and knowledge work (Gandini, 2016).

In recent times, however, distinct efforts have been made to 'provincialize' and 'de-centralize' creative geographies of major cities with 'tales from the margins' (Gibson, 2010). Acutely aware of the predominance of the super-metropolis as empirical sites, some scholars exercise 'epistemic resistance' (Willems, 2014) by refusing to 'go metropolitan' and so turning the investigative lens on physically and symbolically 'remote places' such as 'the tropical-savannah' city of Darwin (Gibson, Luckman, and Willoughby-Smith, 2010), Hay-on-Way, a small town on the Welsh/English border and Stoke-on-Trent in deindustrialized midlands (Oakley and Ward, 2018) or 'the traumatized' New Orleans (Mayer, 2011). Some scholars even suggest remedying 'the urban bias' in $\mathrm{CCl}$ literature by eschewing the empirical focus on inner city spatialities such as cafés, refurbished warehouses or hip clubs (Gibson, 2010: 3) and concentrating instead on rural and 'countryside creativity' (Luckman, 2012) as well as the 'creative suburbia' (Flew, 2012). Luckman (2012: 2) makes a compelling argument in favour of 'locating creative work' in what she calls 'edge-places of creativity' so as to understand the spatial particularities of creative work. She finds that an intimate, affective and practical connection to place is integral to the creative practice of those who work outside the big cities.

The importance of ex-centric places, their situated and contextualised dynamics rather than the formulaic and axiomatic urbanity of the 'creative hubs', has thus received increasing recognition. Such recognition has been increasingly made in light of the claims that digital technologies have diminished the importance of place in media work (Gregg, 2012) while giving rise to a new location-independent labour trend, the so-called 'digital nomadism' (Müller, 2016). McRobbie (2002) had early warned of the risk posed by the intensified digital-technology-enabled requirements in the creative industries for an accelerated mobility, that is to jump blissfully both from job to job but also from one creative hub to the next. According to McRobbie (2002) creative work is 'de-spatialized' as well as 'de-socialized' and hence also 'de-politicized'. In order to salvage the morally-progressive and political engagement with creative work (Banks and Hesmondhalgh, 2009) scholars make efforts to 're-contextualize', 're-localize' and hence 're-socialize' creative work (Alacovska, 2018b; Banks, 2006; McRobbie, 2016). Oakley and Ward (2018: 15) have recently emphatically concluded that 'place matters' as different visions of what 
constitutes 'good life' and 'good creative work' will differ by the localities, either central or peripheral, that artists inhabit.

All these studies are commendable for their political project-resisting the centrality of the supermetropolis as a privileged analytical locus in the studies of creative work. However, the result is most frequently a 'new regionalism' perspective rather than an 'ex-centric' vantage point from outside the West. Despite emphasising 'edge' or 'remote places' these studies nonetheless concentrate on differences 'within localities' (Oakley and Ward, 2018: 15, original emphasis) and not outside. These studies still privilege the central 'creative districts' within these marginal localities, which under the dictate of powerful creative industries policies and city branding, make efforts to resemble the metropolitan creative hubs.

The studies of ex-centric creative work, that is creative work taking place in the non-West, are still sparse. In the past decades however scholars working in a wide variety of disciplines have begun to show interest in non-West creative industries. Most of these efforts concentrate either on some distinctive creative work aspect, for example anthropologists have investigated the 'innovation' work in the advertising industry in Japan (Moeran, 2013) or the globalized dynamics of creative industries policies in Asia (Comunian and Ooi, 2016; Keane, 2013; Kong, 2005) or Africa (De Beukelaer, 2015; Langevang, 2017).

A more consistent effort at incorporating an ex-centric view on cultural production and creative labour can be traced on the pages of this very Journal which, as it behoves an international journal of cultural studies, has as of recently published articles that question the global reach of creative industries discourses and policies (Lobato, 2010 on film-making in Nigeria; Lin, 2018 on media work in Chinese state-owned cultural enterprises; Beltrán and Miguel, 2014 on entrepreneurial labour in Argentinian creative industries). These studies usefully challenge the alleged universal relevance of entrenched theoretical tenets in creative labour studies such as the self-realisation and autonomy of creative work (Lin, 2018). In addition scattered studies, elaborate on the interplay between global and local networks in the non-West creative industries. For example, scholars valuably elucidate the hidden, informal, alternative and 'pirate' South-North circuits of distribution of Nollywood movies, the video-making industry in Nigeria (Lobato and Thomas 2015; Miller, 2012); the informal diaspora-endorsed distribution channels of hip-hop produced in Accra, Ghana (Shipley, 2012) or the telenovelas produced in Colombia (Miller, 2010); and the 'informalized' operations or 'manoeuverability' by transnational media corporations in local media markets (Fung, 2006). Given the tension between urbanity and marginality immanent in the genre, it is the studies of the localized production of hip-hop that have been at the forefront of an implicit de-Westernising project, demanding 'mondialization' or contextualisation of 'world cultures' in specific ex-centric marginal localities (see for example Perullo, 2005 on the production of hip-hop in Dar es Salaam, Tanzania and Schneidermann, 2014 on hip-hop in Kampla, Uganda). MBaye's (2014:397) work on Senegalese hip-hop perhaps goes furthest in 'insisting on the situatedness' and complexity of hip-hop as a form of 'transculture', grappling with localized dynamics of 'generalized social marginalization'. 
In this Special Issue we seek to build on this body of work, while seeking to reconnect original 'excentric' empirical evidence to theory-generation in the studies of creative labour. Below we outline the familiar - Western - story of creative work's informality, indicating how the ex-centric perspective adopted in this Special Issue can open, complicate, destabilise and enrich our understandings of this.

\section{'Provincializing' the informality and precarity of creative work}

Informality has been typically defined as a pervasive feature of creative work. Universalising the experiences of creative work in the West, especially on the Anglo-American orbit, creative labour studies define informality in a dualistic manner (Alacovska, 2018b). On the one hand, creative labour is characterized by labour markets that are informally governed through social networks, social capital, friends and acquaintances rather than quality, knowledge or educational credentials (Grugulis and Stoyanova, 2009; Blair, 2002). On the other hand, creative work is defined as profoundly informal on the basis of informal work environments, which have been frequently found to approximate play and pleasure at work, involving horizontal hierarchical structures and creative autonomy (Neff, 2012; Hesmondhalgh and Baker, 2011; Ross, 2003).

Critical creative labour scholars therefore often establish a link between informality and precarity. 'Informal networking', 'informal contacts', 'informal learning' and 'informal knowledge' have been thought of as individualized solutions to systemic problems: insecure, deregulated, contingent, casualized creative labour markets (McRobbie, 2002: 519-520; Neff, 2012) whereby an individual worker shoulders the costs of re-qualification, retirement or sick leave. When project-by-project freelance employment is the norm and unionization weak then informal social connections (rather than formal labour market institutions) function as individualized unemployment insurance. In this way, informal networking becomes a response to the 'informal hiring', and so morphs into yet another work activity requiring after-work partying, always-on work ethic and a passionate connection to work (Gill, 2014, 2007; Neff, 2012). The informal governance of creative labour markets has thus been repeatedly confirmed as a cause of burnout, self-exploitation and long-term sickness triggering also a range of social inequalities such as gender, race and class inequalities, as many are unable to sustain the informal 'free labour' required by networking and are so prevented from accessing the 'old boy's club' responsible for the informal 'homosocial' hiring (Gill and Pratt, 2008; Alacovska, 2017). It is this individualizing power of informality that as Jones and Pringle (2015) argue render the existing inequalities 'unmaneagable', escaping labour regulation, anti-discrimination and equal opportunities legislation.

Not only are the creative labour markets informal, but the creative workplaces as well. As Banks and Hesmondhalgh (2009: 417) observe creative workplaces 'are characterised by informality, team-working and the radical rejection of traditional forms of management and organisations'. Play ethic and 'bohemian corporate cultures' (Ross, 2003) have thus become instituted as a compulsory feature of creative working environments, and even extended to traditional organisations. Critical creative labour scholars again unmask the workplace informality as a veil of burnout, overwork and underpay (Hesmondhalgh and Baker, 2011; Neff, 2012). 
However, beyond such understandings of informality, ex-centric studies help illuminate that creative workers engage routinely and often tacitly in a multifarious, complex and fluid array of informal economic and labour practices that are rarely documented in mainstream accounts. Creative work is infused in long-term kinship, friendship and neighbourhood relational ties which do not abide always or necessarily by monetary, profit-seeking, utilitarian logic of social networks, but by the non-monetary logic of community, morality, reciprocity and mutuality (Schneidermann, 2014; Alacovska, 2018a,b) . If all economic activities are social interactions, then when engaging in labour practices creative workers pursue 'relational work' - 'the creative effort people make in establishing, maintaining, negotiating, transforming, and terminating interpersonal relationships' 'that constitute economic activity' (Zelizer, 2012: 149). If we approach the informality of creative work, as work or economic activities infused in relational webs of reciprocity (as opposed to formal-ized market and workplace units), then we can challenge the individualizing characterisation of creative work and point to its alternative readings such as the understanding of creative work as a 'social enterprise' (McRobbie, 2016, see Dinardi in this volume), as intergenerational solidarity and close-knit community help (Leung and Cossu in this volume), as a collectivised process of community-based cultural production and consumption (see Maclean and Iqani, this volume) or a shared occupational coping strategy for dealing with inefficient institutional frameworks (see Kuleva, this volume). If approached in this way, then creative work resembles 'moral work' whereby economic activities always involve considerations of value, responsibility and solidarity (Banks, 2006). If the informality of creative work is provincialized, in the ways this Special Issue proposes, then the definition of creative work comes closer to how feminist scholarship has defined labour. Through a feminist lens, economic activities are always embedded in non-monetary and nonmarket interpersonal and community relations of care and reciprocity, a relational labour-nexus that has been traditionally linked to women and the 'informal'-domestic labour of care (Folbre, 1995; Tronto, 1993). Such definition of creative work, however, should not call forth 'retraditionalization of gender' (Adkins, 1999) by assigning more nurturing, caring and emotional roles to creative workers, especially women. Rather it calls on scholars to take seriously feminist critiques that challenge the supposed 'newness' of immaterial labour (Federici, 2006). Indeed, it may even ask, as Laura Briggs (2017) has done, whether 'all politics is reproductive politics'. It may even engage with the question of whether creative labour may actually also be considered a form of care labour, geared towards making a social difference in local communities, neighbourhoods or artistic scenes (an aspect considered by all the contributions to this Special Issue, as well as by recent work by Banks, 2017 on creative justice).

Ex-centric countries are often taken to be synonymous with 'unorthodox informal economies'. Excentric countries, whether post-communist or post-colonial, have been considered in their entirety as informal economies and societies (invoking connotations of backwardness, underdevelopment, roguishness) as opposed to the formal economies of the 'centre' (invoking order, modernity, and fairness). This dichotomy has been fiercely challenged (Williams and Nadin, 2012). Maclean (this volume) argues that the boundaries between the formal and the informal are in themselves racialized and colonial, imposed by development agencies, financial institutions and governments from 'the centre'. Writing of fashion production in Bolivia, she further contests the familiar Western story of precarization of cultural workers: 'The majority of the economy is informal, state and public institutions 
are rooted in colonial power, cities have expanded rapidly and informally due to rural-urban migration, and there has been no welfare state to roll back so as to create a "precarious" cultural workforce'.

Scholars of informality have thus started questioning the normativity of the formal by expounding on the fluidity between formal and informal labour practices (even in the global North, see Snyder, 2004). Informality so defined ceases to be dualistic, and encompasses a varied array of labour practices that ranges from formal paid work and formal unpaid work (such as internships) to informal unpaid work, taking place in communities, localities and kinship ties (in the form of voluntary work, mutual aid and favour-swapping, for example) (Wi'lliams and Nadin, 2012; Alacovska 2018b). The pervasive and manifold informalities so defined are geared as much to securing economic benefit and market advantage as to perpetuating social reproduction and mutuality. Informality here takes the polyvalent and innovative form of webs of reciprocity, mutual obligations, moral economies of favour and kinship ties, encompassing also a range of 'semi-illegal' economic activities that defy regulation, such as tax evasion, pilfering, clientelism, cash-in-hand wages and 'hand-shake deals' (Comaroff and Comaroff, 2012; also see contributions to Lindell, 2010; Williams and Nadin, 2012).

It is this most notable aspect of informality, as illegal or semi-illegal trade and exchange that has found inroads recently into cultural and communication studies. However, this focus is squarely put on the socalled informal media economies, and does not extend to actual labour practices, as such. For example, scholars have tackled 'informal' distribution networks and the ensuing illegal activities by a range of trickster figures or intermediaries such as smugglers, pirates, hackers and their practices of unlicensed printing, parallel import of cultural goods, unauthorised copying and similar (Lobato and Thomas, 2015; Miller, 2012). Approaching informal labour practices as 'black economic practices' and ascribing them to 'illegal' workers positioned outside the formalized and regularized media economies, resulted in cultural studies' somewhat limiting treatment of informality as directly opposed to formality. In this view, informality is considered an anomaly, a backward operation to be eradicated whereas the informal workers so involved are considered uneducated, marginalized and shadow. In contrast, formal media economies are putatively desirable, regularized and normative. As a consequence of this strict formal/informal work divide, such an approach tends to disregard the multifarious and seamless overlap between informal and formal labour practices.

If informality is pervasive and multifarious, then discussion about creative work and its precarity must be complexified. If creative labour is embedded in intense socialities defined through their mutuality and reciprocity rather than profit-motivated exchange logic, then we must seek to understand the moral economies of creative labour beyond limited 'market' and 'managerial' perspectives (Banks, 2006; Lee, 2012; Hesmondhalgh and Baker, 2011). Informality may then be read differently - as a form of mutual aid, community-based solidarity, and a mode of resource redistribution, but also as informal contracting, informal labour arrangements and informal work norms. Dinardi (this volume) writing about cultural work in Rio's favelas insists that informality be valued in multiple different ways, even as a labour of resistance and radical action. Informality thus has a myriad of different meanings, faces and guises in different places that have to be taken seriously in the analysis of creative work.

\section{The multifarious and ambivalent valences of creative work's informality}


This special issue therefore brings together original, empirically-grounded scholarship on creative labour in various non-West media/creative industries. Dinardi investigates creative labour as it unfolds in the informal settlements of Rio de Janeiro's favelas; Ozimek explores the informal contractual arrangements of Polish video game producers; Kuleva focuses on informal artistic labour practices in Russia's privately owned museums; Iqani concentrates on the work of informal cultural intermediaries in the luxury business in South Africa; Maclean explores the production and consumption of pollera fashion as embedded in informal, relational infrastructures of communities and neighbourhoods in Bolivia, and last but not least in a joint paper Leung and Cossu comparatively examine the informal labour practices of digital entrepreneurs in East Asia, namely in Taiwan and Thailand.

By providing rich empirical insight, all contributions, in their own way, probe the applicability of the hitherto developed concepts of creative work's informality and precarity. The overall focus is on how creative work is sustained by informal practices-i.e., by practices embedded in non-market social relations sustained by moral values (mutuality, a sense of reciprocity, kinship ties and selfless commitment to a common good) and not only rational calculation or market instrumentalism but also by practices that feature deep under the radar of tax, employment and social work authorities and institutions. Taking stock of local, national and regional specificities, all contributions explore: 1) the diverse array of informal economic strategies to which creative workers resort in order to make a living and/or sustain entrepreneurial activities; 2 ) the complex overlap between paid/unpaid/voluntary/nonprofit/legal/semi-illegal creative labour practices; 3 ) the interplay between communication technologies and informal cultural entrepreneurship; 4) the informal organisation of specific industries; 5) the ways in which economic practices are structured and influenced by moral dispositions, cultural norms and a quest for the betterment of society.

The informal, then, materialises in multiple different ways in this collection of six ex-centric studies. For Kate Maclean 'the informal economy is how most people in the world earn their living- and it is not until formal powers appear, in the guise of colonisers, development agencies or international financial institutions, that these activities are even constructed as "informal"' - they are just the way things are. Writing about the uptake of Aymara or 'chola' indigenous fashion in Bolivia, she comes up against the difficulty of finding a language to talk about this in the context of an Anglophone publication, without depicting it in terms of how it differs from/is framed in alterity to the norms of fashion in the global North. She argues that existing scholarship has been developed around multiple binaries for example those between tradition and modernity, consumption and production, culture and economy and even authenticity and appropriation. Yet 'indigenous women who have worked all their lives and conditions of extreme precarity, who are creating designs that are essential to the re-creation of traditions that continue to underpin economic exchange, whilst also being recognised as innovative and luxurious consumer items, and who have been able to break into traditionally elite spaces in the city on their own terms, present strong challenges to these dichotomies.'

Mehita Iqani's work on social media brand influencers in South Africa further challenges some wellknown binaries - above all disrupting the way that Africa is traditionally seen from the North/West and its agencies. As part of a project on Africa as a "new frontier" for luxury consumer markets, she examines the role of brand ambassadors as cultural labourers. The analysis is framed through critical 
scholarship that defines the work of social media influencers and brand ambassadors as a form of informal value creation which operates at the level of micro-celebritization, brand storytelling, and role modelling aspirational consumer citizenship in a way that has particular meaning for consumer cultures in the global South.

Cecilia Dinardi's paper offers a nuanced ethnographic reading of Favela Criativa in Rio de Janeiro, in which funding from state government and International Development Bank is supporting young people's creative and cultural work. Starting from a critical sociological perspective that problematizes the easy transfer of creative economy policies, she nevertheless argues that the Favela Criativa has widened the visibility of the favelas' cultural work, increased the public support available for popular cultural forms, and, crucially, developed practical strategies for working with informality rather than denying it or excluding it. Whilst remaining attentive to the risks of top-down managerial interventions guided by market logics, Dinardi argues that the programme requires us to 'rethink informality and precarity' beyond negative concepts. Her paper sheds light on how creative entrepreneurship with/among insurgent arts collectives and cultural organisations demands both access to the city and 'the right to have rights'.

Leung Wing-Fai and Alberto Cossu focus on East Asia, arguing that socially mobile young people in Taiwan and Thailand are ex-centric subjects for whom digital entrepreneurship offers new experiences of work shaped by both the reception and uptake of neoliberal ideals, and by the particular political and economic realities of those two countries. In Taiwan Leung draws on more than 70 interviews to ask how the 'American Ideological Apparatus' of entrepreneurialism interacts with benshengren (native Taiwanese) notions of baishou qija ('starting from nothing; building a life from scratch'). In Thailand Cossu's account examines digital entrepreneurship against the backdrop of migration, financial crisis, and a changing education system. In both countries the informal economy has been associated with the working class, thus the new informality of digital entrepreneurs constitutes a class shift. Leung and Cossu examine how this is mediated by family and by generations, particularly the so-called $22 \mathrm{~K}$ generation in Taiwan, for whom entrepreneurship may be understood as 'an alternative to political action'. In many respects the paper shows the spreading out of neoliberalism and entrepreneurialism via the diffusion of bohemian creative industries discourse, but it also highlights the limits of this as it comes up against the political and economic realities of the two countries.

Margarita Kuleva turns the focus on post-Soviet Russia, and the art world. Based on 25 interviews her paper considers what she dubs a 'transitional cultural economy', one that is shifting between a Sovietera cultural monopoly to a market-based art system. Starting from the observation that informal labour economies are deeply embedded in the Russian creative sector, her work offers a fascinating glimpse of the way in which new privately funded art centres are moving into a sphere previously dominated by the state. She explores how new market ideologues are consciously emulating the 'Tate Moderns' or 'MoMAs' of the metropolitan West, promoting neoliberal ideals of competition and meritocracy, while at the same time preserving many features of the old system such as blat, favour-swapping and clientelism. Talking with art workers, her research offers a unique take on what she sees as 'informal labour perspectives in formal organisations'. 
Finally, Anna Ozimek's paper considers work in the Polish videogames industry. Rather than accepting a binary between formal and informal, she explores the areas 'in between', the semi-legal, 'grey' forms of contract available, drawing on interviews exploring how workers themselves made sense of - and actively pursued - certain forms of contract rather than others - even when they might appear to be against their longer term interests. Locating the project in a growing concern about 'fraudulent' contracts, Ozimek looks at 'civil law contracts' in which workers are deprived of protections, yet actually prefer to work 'below the line' both for financial (tax) reasons and for the autonomy it affords. While noting problematic employer practices, her work complicates narratives of 'grey work' as marginalised or stigmatised and helps to illuminate the factors that may make it attractive for increasing numbers of workers.

\section{Conclusion}

Extending the geographical reach of creative labour studies should not be an aim in itself in a deWesternising project. Merely increasing diversity in geographically-distributed cases, as in area studies, would neither redress the problem of asymmetric knowledge production nor provide a robust alternative to the current epistemological ethnocentrism of creative labour studies. Instead, the goal here is to feed and factor the knowledge of the lived dynamics of creative work outside the West directly into the development and refinement of the analytical tool-kit and theoretical concepts of creative labour studies.

The study of creative work's informality in 'ex-centric countries' should become a source of theory building, not merely an aggregation of scattered case studies or tokenistic 'glance' Southwards or Eastwards before returning to the old agenda. As post-crisis and post-austerity Western countries, distressed by severe political, refugee and corporate scandals, 'evolve towards ex-centric countries' (Comaroff and Comaroff, 2012), and as informalization has already moved westward and northward through transnational and flexible management of global supply chains (Castells and Portes, 1989; Sassen, 1998), knowledge about the multifarious informalities outside the West may help enrich our understanding of creative work in Euro-America, as well as affording us a fuller understanding of the complexities of creative labour across the globe. Moreover, creative work in the countries outside the West is drastically precarious, as it is not only insecure and contingent in itself, but it happens in a context of radical political, social and economic uncertainties and turmoil. An ex-centric perspective on informality and precarity then promises to both take forward and 'talk back' to existing literatures in important ways.

The effort at de-Westernising or provincializing creative labour studies becomes especially pertinent and urgent if we bear in mind that governments outside the West resort regularly to "Xeroxing" policy making' that is uncritically replicating, adopting and implementing allegedly global and transnational, but essentially Western and neoliberal, cultural and creative industries policies (Pratt, 2009: 10; O'Brien, 2015). The creative industries policies in the West have already been severely criticised for their contribution to labour precarity mainly because under the guise of passionate and informal work such policies perpetuate gender, race and ethnic inequalities, as well as lead to workplace abuse, exploitation and self-commodification (McRobbie, 2016; Hesmondhalgh and Baker, 2012; Gill and Pratt, 2008; Gill, 
2002). This special issue aims to provide an initial empirical insight into the ways that creative work is experienced outside the West in a context of growing fascination on the part of ex-centric countries with creative industry policies.

In the current globalized socio-economic set-up of research and academia, there are inevitably ironies involved in a de-Westernising project, and we wanted to end by reflecting on our own locations and the genesis of this project. Structural issues have to be critically acknowledged and given serious attention when developing a de-Westernising project. Selective research funding schemes with more-or-less predetermined research-cum-economic-development-agendas, the continuing hegemony of English language as a medium for scientific results dissemination, as well as the global importance of Western academic institutions have shaped the outcome of this Special Issue. This special issue was inspired by and developed within the framework of a regional project led by the first author funded by the Swiss Agency for Development and Cooperation and administered by the University of Fribourg in Switzerland in close collaboration with local non-governmental associations of artists located in Macedonia and Albania (in the Western Balkans). In line with such funding-driven exigencies the project aimed to examine the value of creative industries for 'regional economic development'. The project did not start explicitly or purposefully as a de-Westernising project. An unambitious agenda drove the project initially. The project aimed to deductively apply an already-ready theoretical frame (as distilled from the 'mainstream' studies of creative work) to empirically-generated evidence in a non-Anglo-American context. In fact, an assumption that creative work unfolds more or less universally across cultures was somewhat implicit in the research design. 'The epistemic resistance' (Willems, 2014) took shape gradually, as a direct upshot of the researchers' growing dissatisfaction with the available 'hegemonic' theoretical apparatus that did not seem to fully capture the 'indigenous' experiences and practices of creative work in the studied context. From here an ex-centric perspective on creative work started gradually to assert its indispensability.

In addition, the funding scheme featured a strong capacity-building dimension that envisaged Western scholars acting as mentors to ensure a European-level quality of 'ex-centric' research (implicitly assuming that such 'universal' quality lacked or was insufficient in the region). That is, we contend, a notion of Western academic superiority was built into the very framing of the funding regime, creating a structurally unequal relation that we have both worked within (accepting funding) and resisted (through the critical work involved in this special issue). The co-author was involved in the project as an advisor and mentor - a role, we would note, that is deeply problematic and ambivalent- the self-evidence of whose agendas we seek to interrogate. There are therefore particularly delicate issues of power, voice and location entangled in this involvement, on which both authors have reflected hard, in relation to multiple axes that relate to place, language (the dominance of English) and academic and para-academic institutions (funding bodies, journals, etc) as well as race, gender, and class. We engage in this, from our different positions, as critical scholars invested in challenging Western hegemonic knowledge, and in interrogating and opening up taken-for-grated agendas- even those with which we have ourselves - in relation to a certain Western critical position on creative labour - been involved in constructing. Ultimately, we believe that a more expanded and expansive canon of scholarship and voices originating from the 'global South' and reflecting its varied cosmologies and epistemologies must displace the 
currently narrow set of 'Western' references. A future de-Westernising project has to consistently engage with and think through concepts developed 'elsewhere' and have been perhaps also written in local languages. This will in turn help future de-Westernising efforts to encompass contributions that have not been channelled via the academic institutions situated on the very same 'Anglo-American orbit' that we try to dismantle (by incorporating, for example, authors from 'ex-centric' countries that have not been long inserted in the Western academia, as it was necessary and inevitable, for this Special Issue).

\section{References}

Adkins L (1999) Community and economy: A retraditionalization of gender?. Theory, Culture \& Society 16(1): 119-139.

Alacovska A (2018a, online first) 'Keep going, keep hoping': towards a hopeful sociology of creative work. Sociological Review doi.org/10.1177/0038026118779014

Alacovska A (2018b) Informal creative labour practices: a relational work perspective. Human Relations 71(12): 1563-1589.

Alacovska A (2017) The gendering power of genres: How female Scandinavian crime fiction writers experience professional authorship. Organization 24(3): 377-396.

Ang I (2001) On not speaking Chinese: Living between Asia and the West. Psychology Press.

Banks $M$ and Hesmondhalgh, D (2009) Looking for work in creative industries policy. International Journal of Cultural Policy 15(4): 415-430.

Banks M (2006) Moral economy and cultural work. Sociology 40(3): 455-472.

Banks M (2012) Maclntyre, Bourdieu and the practice of jazz. Popular Music 31(1): 69-86.

Barraclough D and Kozul-Wright Z (2008) Creative Industries and Developing Countries: Voice, Choice and Economic Growth. London: Routledge.

Beltrán GJ \& Miguel P (2014) Doing culture, doing business: A new entrepreneurial spirit in the Argentine creative industries. International Journal of Cultural Studies 17(1): 39-54.

Bhabha H (1994) The Location of Culture. New York: Routledge.

Briggs L (2017) How All Politics Became Reproductive Politics: From Welfare Reform to Foreclosure to Trump (Vol. 2): University of California Press.

Castells M and Portes A (1989) The Informal Economy: Studies in Advanced and Less Developed Countries. Baltimore: John Hopkins University Press.

Césaire, A (2000) Discourse on colonialism. New York: Monthly Review Press.

Comaroff J and Comaroff JL (2012) Theory from the South: Or, how Euro-America is evolving towards Africa. Anthropological Forum 22(2): 113-131.

Comunian R and Ooi C-S (2016) Global aspirations and local talent: the development of global creative higher education in Singapore. International Journal of Cultural Policy 22(1): 58-79.

Curran J and Park MJ (2000) Beyond globalization theory. In J. Curran \& M.-J. Park (Eds.), De-

Westernizing Media Studies (pp. 3-8). London: Routledge

De Beukelaer C (2015) Developing cultural industries: Learning from the palimpsest of practice. European Cultural Foundation.

Federici S (2004) Caliban and the Witch. Autonomedia.

Flew T (2012) Creative suburbia. Rethinking urban cultural policy - the Australian case. International Journal of Cultural Studies 15(3): 231-246.

Florida R (2002) The rise of the creative class. New York: Basic Books.

Folbre N (1995) 'Holding hands at midnight': The paradox of caring labor. Feminist Economics 1(1): 73-

92. 
Fung A (2006) 'Think globally, act locally' China's rendezvous with MTV. Global Media and Communication 2(1): 71-88.

Gandini A (2016) The Reputation Economy. London: Palgrave Macmillan. .

Gibson C (2010) Guest Editorial-Creative Geographies: tales from the 'margins'. Australian Geographer 41(1): 1-10.

Gibson C, Luckman S and Willoughby-Smith J (2010) Creativity without borders. Rethinking remoteness and proximity. Australian Geographer 41(1): 25-38.

Gill R (2002) Cool, creative and egalitarian? Exploring project-based new media in Europe. Information, Communication and Society 5(1): 70-89.

Gill R (2007) Technobohemians or the New Cybertariat? New Media Work in Amsterdam a Decade after the Web. Amsterdam: Notebooks.

Gill R and Pratt A (2008) In the social factory. Immaterial labour, Precariousness and cultural work.

Theory, Culture and Society 25(7/8): 1-30.

Giraldo I (2016) Coloniality at work: Decolonial critique and the postfeminist regime. Feminist

Theory 17(2): 157-173.

Grugulis I and Stoyanova D (2012) Social capital and networks in film and TV: Jobs for the boys?.

Organization Studies 33(10): 1311-1331.

Hanitzsch T (2007) Deconstructing journalism culture: Toward a universal theory. Communication Theory 17(4): 367-385.

Harding S (1993) Rethinking standpoint epistemology: What is strong 'objectivity'? in Alcoff L. and Potter E (eds.) Feminist Epistemologies. London: Routledge.

Hesmondhalgh D and Baker S (2011) Creative Labour: Media Work in Three Cultural Industries. London:

Routledge.

Hesmondhalgh D (2012) The Cultural Industries. London: Sage.

Jones D. \& Pringle JK (2015) Unmanageable inequalities: sexism in the film industry. The Sociological

Review 63(1_suppl): 37-49.

Keane M (2013) Creative industries in China: Art, design and media. John Wiley \& Sons.

Kong L (2005) The sociality of cultural industries: Hong Kong's cultural policy and film industry.

International Journal of Cultural Policy 11(1): 61-76.

Langevang T (2017) Fashioning the Future: Entrepreneuring in Africa's Emerging Fashion Industry. The European Journal of Development Research 29(4): 893-910.

Lee $D$ (2012) The ethics of insecurity. Risk, individualization and value in British independent television production. Television \& New Media 13(6): 480-497.

Lin J (2018, online first) Be creative for the state: Creative workers in Chinese state-owned cultural enterprises. International Journal of Cultural Studies https://doi.org/10.1177/1367877917750670 Linde, I (2010) Africa's Informal Workers. London: Zed Books.

Lobato R \& Thomas, J (2015) The informal media economy. John Wiley \& Sons.

Lobato R (2010). Creative industries and informal economies: Lessons from Nollywood. International Journal of Cultural Studies 13(4): 337-354.

Luckman S (2012) Locating Cultural Work: The Politics and Poetics of Rural, Regional and Remote creativity. London: Palgrave Macmillan.

Mayer V (2011) Below the line: Producers and production studies in the new television economy. Duke University Press.

Mbaye JF (2014) Hip Hop Politics: Recognising a Southern Complexity. In: S. Parnell \& S. Oldfield (Eds.), The Routledge Handbook on Cities of the Global South. (pp. 396-412). London, UK: Routledge.

McRobbie A (2002) From clubs to companies: Notes on the decline in political culture in speeded up creative worlds. Cultural Studies 16(4): 516-531.

McRobbie A (2016) Be Creative: Making a Living in the New Culture Industries. London: Polity. 
Miller J (2010) Ugly Betty goes global: Global networks of localized content in the telenovela industry. Global Media and Communication 6(2): 198-217.

Miller J (2012). Global Nollywood: The Nigerian movie industry and alternative global networks in production and distribution. Global Media and Communication 8(2): 117-133.

Moeran B (2013) A Japanese advertising agency: An anthropology of media and markets. Routledge.

Müller A (2016) "The digital nomad: Buzzword or research category?." Transnational Social Review 6(3): 344-348.

Nabudere D (2011) Afrikology, philosophy and wholeness: An epistemology. Pretoria: Africa Institute of South Africa.

Neff G (2012) Venture labour. MIT Press.

O'Brien D (2015) Business as usual: Creative industries and the specificity of the British state. In Oakley K and Connor J (eds.) The Routledge Companion to the Cultural Industries. London: Routledge.

Oakley K \& Ward J (2018) The art of the good life: culture and sustainable prosperity. Cultural Trends 27(1): 4-17.

Ong A (2006) Neoliberalism as Exception: Mutations in Citizenship and Sovereignty. Durham, NC: Duke University Press.

Orgad S (2014) Media representation and the global imagination. John Wiley \& Sons.

Perullo A (2005) Hooligans and heroes: Youth identity and hip hop in Dar Es Salaam, Tanzania. Africa Today 51(4): 75-99.

Peterson, AR (1997) Creating Country Music. Fabricating Authenticity. University of Chicago Press. Pratt AC (2002) Hot jobs in cool places. The material cultures of new media product spaces: the case of south of the market, San Francisco. Information, Communication \& Society 5(1): 27-50.

Pratt AC (2009) Policy transfer and the field of the cultural and creative industries: What can be learned from Europe?, in Kong L and O'Connor J (eds.) Creative Economies, Creative Cities: Asian-European Perspectives (pp. 9-24). London: Springer.

Roy A and Ong A (2011) Worlding Cities: Asian Experiments and the Art of Being Global. John Wiley \& Sons.

Ruddick S (2015) Situating the Anthropocene: planetary urbanization and the anthropological machine, Urban Geography 36(8): 1113-1130.

Sandoval M (2017, online first) From passionate labour to compassionate work: Cultural co-ops, do what you love and social change. European Journal of Cultural Studies

Santos B (2014) Epistemologies of the south: Justice against epistemicide. Boulder: Paradigm Publishers.

Sassen S (1998) Globalization and its Discontents. New York: New Press.

Scharff C (2016) The psychic life of neoliberalism: Mapping the contours of entrepreneurial subjectivity.

Theory, Culture \& Society 33(6): 107-122.

Schneidermann N (2014) 'Mic Power': 'Public' connections through the hip hop nation in Kampala.

Ethnography 15(1): 88-105.

Scott AJ (2005) On Hollywood. The Place, the Industry. Princeton University Press.

Shipley JW (2012) Living the hiplife: Celebrity and entrepreneurship in Ghanaian popular music. Duke University Press.

Shome R (2009) Post-colonial reflections on the 'internationalization' of cultural studies. Cultural Studies 23(5-6): 694-719.

Simone A (2001) On the worlding of African cities. African Studies Review 44(2): 15-41

Snyder KA (2004) Routes to the informal economy in New York's East Village: Crisis, economic and identity. Sociological Perspectives 47(2): 215-240.

Sreberny A (2000) Television, gender, and democratization in the Middle East. in Curran, J and Park, M (eds) De-Westernizing media studies. London: Routledge, pp. 63-78.

Taylor S and Luckman S (2018) The 'New Normal' of Working Lives: Critical Studies in Contemporary 
Work and Employment. London: Palgrave.

Trinh T. Minh-ha (1991) When the Moon Waxes Red: representation, gender and cultural politics. New York: Routledge

Tronto JC (1993) Moral boundaries: A political argument for an ethic of care. Psychology Press.

Waisbord S and Mellado C (2014) De-Westernising communication studies: A reassessment.

Communication Theory 24: 361-372.

Wang G (2010) De-Westernizing Communication Research: Altering Questions And Changing

Frameworks. London: Routledge.

Willems W (2014) Provincializing hegemonic histories of media and communication studies: toward a genealogy of epistemic resistance in Africa. Communication Theory 24: 415-434.

Williams CC and Nadin S (2012) Work beyond employment: Representations of informal economic activities. Work, Employment and Society E-special issue: 1-10

Wright KH (1998) Dare we de-centre Birmingham? European Journal of Cultural Studies 1(1): 33-56.

Zelizer VA (2012) How I became a relational economic sociologist and what does it mean? Politics and

Society 40(2): 145-174 